\title{
Higher Temperature Thermal Barrier Coatings with the Combined Use of Yttrium Aluminum Garnet and the Solution Precursor Plasma Spray Process
}

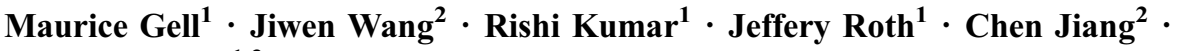 \\ Eric H. Jordan ${ }^{1,3}$
}

Submitted: 1 November 2017/in revised form: 27 December 2017/Published online: 9 February 2018

(C) ASM International 2018

\begin{abstract}
Gas-turbine engines are widely used in transportation, energy and defense industries. The increasing demand for more efficient gas turbines requires higher turbine operating temperatures. For more than 40 years, yttria-stabilized zirconia (YSZ) has been the dominant thermal barrier coating (TBC) due to its outstanding material properties. However, the practical use of YSZbased TBCs is limited to approximately $1200{ }^{\circ} \mathrm{C}$. Developing new, higher temperature TBCs has proven challenging to satisfy the multiple property requirements of a durable TBC. In this study, an advanced TBC has been developed by using the solution precursor plasma spray (SPPS) process that generates unique engineered microstructures with the higher temperature yttrium aluminum garnet (YAG) to produce a TBC that can meet and exceed the major performance standards of state-of-the-art air plasma sprayed YSZ, including: phase stability, sintering resistance, CMAS resistance, thermal cycle durability, thermal conductivity and erosion resistance. The temperature improvement for hot section gas turbine materials (superalloys \& TBCs) has been at the rate of about $50{ }^{\circ} \mathrm{C}$ per decade over the last 50 years. In contrast, SPPS YAG TBCs offer the near-term potential of a $>200^{\circ}$ $\mathrm{C}$ improvement in temperature capability.
\end{abstract}

Chen Jiang

chenjiang.chn@gmail.com

1 Institute of Materials Science, University of Connecticut, Storrs, CT, USA

2 HiFunda LLC, Salt Lake City, UT, USA

3 Department of Mechanical Engineering, University of Connecticut, Storrs, CT, USA
Keywords CMAS resistance $\cdot$ erosion resistance $\cdot$ plasma spray $\cdot$ thermal barrier coatings $\cdot$ thermal cycling $\cdot$ yttrium aluminum garnet

\section{Introduction}

Thermal barrier coatings (TBCs) are used to achieve higher operating temperatures while protecting the metallic substrates from degradation and failure in gas-turbine engines. For over 30 years, 6-8 wt.\% yttria-stabilized zirconia (YSZ) has been the dominant TBC topcoat material due to a combination of outstanding material properties (Ref 1-3), including low thermal conductivity, high coefficient of thermal expansion and high toughness for a ceramic. For YSZ TBCs, at an operating temperature of $1200{ }^{\circ} \mathrm{C}$ or greater, the non-transformable $t^{\prime}$-phase, present in the assprayed YSZ coating, destabilizes into tetragonal and subsequently transforms into cubic and monoclinic phases upon heating/cooling operations, with a volume expansion of 3-5\% that has a detrimental effect on TBC durability (Ref 4). YSZ is also limited to about $1200{ }^{\circ} \mathrm{C}$ by a rapid rate of sintering and degradation by molten CMAS (calcium-magnesium-aluminosilicate) deposits.

For decades, a large number of ceramic materials have been proposed and evaluated as higher temperature, lower thermal conductivity TBC candidates to improve gas turbine efficiency and reduce fuel consumption. The candidate advanced TBCs have been the subject of a number of review papers (Ref 5-10). The most commonly studied materials include: (1) zirconia-based systems with dopants, such as $\mathrm{CaO}, \mathrm{MgO}, \mathrm{Sc}_{2} \mathrm{O}_{3}, \mathrm{CeO}_{2}, \mathrm{Ta}_{2} \mathrm{O}_{5}$ and $\mathrm{HfO}_{2}$, that can improve the phase stability of YSZ (Ref 11-15); (2) rare earth zirconates crystallized in the ordered pyrochlore structure, such as $\mathrm{La}_{2} \mathrm{Zr}_{2} \mathrm{O}_{7}, \mathrm{Nd}_{2} \mathrm{Zr}_{2} \mathrm{O}_{7}$, and $\mathrm{Gd}_{2} \mathrm{Zr}_{2} \mathrm{O}_{7}$, that 
have higher melting points, phase stability and lower thermal conductivities than those of YSZ (Ref 16-18); (3) perovskite materials that have very high melting points. Many of these advanced TBCs exhibit some superior properties to YSZ, including higher temperature capability and reduced thermal conductivity, but usually lack one or more engine critical properties, including thermal cycle durability and/or erosion resistance. These property limitations have restricted the application of most advanced TBCs. An exception is gadolinium zirconate (Ref 19), despite exhibiting poorer erosion resistance compared to YSZ (Ref 20, 21).

Bulk yttrium aluminum garnet (YAG) is a well-known oxide that has some desirable physical and mechanical properties in comparison with YSZ for higher temperature TBC applications (Table 1), such as high temperature phase stability up to its melting point $\left(1970{ }^{\circ} \mathrm{C}\right)(\operatorname{Ref} 22)$ and decreasing thermal conductivity with temperature (Ref 23). YAG also has higher hardness, lower density and is an excellent oxygen diffusion barrier (Ref 24). Previous studies have shown that traditional APS YAG TBCs can be deposited with an amorphous or a mixed amorphous/ crystalline phase structure. TBCs with both structures show poor durability because of the transformation strains induced from amorphous to crystalline upon heating and the greater thermal expansion mismatch strains with an asdeposited crystalline microstructure (Ref 25, 26).

The SPPS process (Fig. 1) is a modification of the widely used, commercial air plasma spray (APS) process, which uses powder as feedstock materials. In the SPPS process, a liquid precursor, containing the cations to be deposited, is injected into the plasma plume (Ref 33). The atomized precursor droplets undergo a series of physical and chemical changes in the plasma, including breakup, evaporation and precipitation, shell fragmentation, pyrolysis and melting processes (Ref 34, 35) and are deposited as ultra-fine splats (Fig. 1 inset). It was shown before that the SPPS process produces a number of unique microstructural features that confer improved properties to SPPS YSZ TBCs (Ref 36-40). These include: (a) ultra-fine splats that provide enhanced inter-splat bonding with increased in-plane TBC toughness (Ref 40), (b) throughthickness, vertical cracks that provide strain tolerance with enhanced thermal cyclic durability, (c) porosity that can be varied over a wide ranges, (d) planar arrays of porosity, also called inter-pass boundaries (IPBs) (Ref 41), that can reduce thermal conductivity. The key impetus for this work on SPPS YAG TBCs was to determine whether these unique microstructural features can overcome the larger thermal expansion mismatch strains and the poorer toughness of YAG compared to YSZ. Preliminary results in this regard were promising (Ref 42).

\section{Experimental Procedures}

\section{Materials Preparation and Characterization}

YAG $\left(\mathrm{Y}_{3} \mathrm{Al}_{5} \mathrm{O}_{12}\right)$ solution precursors (oxide loading around $150 \mathrm{~g} / \mathrm{L}$ ) were prepared by mixing stoichiometric amounts of yttrium (III) nitrate hexahydrate $\left(\mathrm{Y}\left(\mathrm{NO}_{3}\right)_{3} \cdot 6\right.$ $\mathrm{H}_{2} \mathrm{O}$, Alfa Aesar, Ward Hill, MA) and aluminum nitrate nonahydrate $\left(\mathrm{Al}\left(\mathrm{NO}_{3}\right)_{3} \cdot 9 \mathrm{H}_{2} \mathrm{O}\right.$, Alfa Aesar, Ward Hill, MA) in distilled water. The thermal characteristics of precursor solutions were measured with DSC-TGA (SDT Q-600, TA Instruments New Castle, DE) at a heating rate of $10^{\circ} \mathrm{C} / \mathrm{min}$ and a $100 \mathrm{ml} / \mathrm{min} \mathrm{N}_{2}$ flow. Viscosity of the precursor was measured using Ubbelohde glass viscometers (Cannon Instrument Company, State College, PA).

Bond-coated substrates and baseline OEM APS YSZ specimens, $25.4 \mathrm{~mm}$ in diameter and $3.5 \mathrm{~mm}$ in thickness, were provided by a gas turbine manufacturer. The specimens to be coated with 200-250 $\mu$ m thick SPPS YAG TBC have a Haynes 230 superalloy, a $\sim 100-\mu$ m-thick HVOF MCrAlY bond coat, and a $\sim 25$ - $\mu$ m-thick APS YSZ inner layer (Fig. 3a). Engine OEM supplied baseline TBC specimens with $\sim 250-\mu \mathrm{m}$-thick APS YSZ on the same substrates, and bond coats (Fig. 3b) were tested at the same time with the SPPS YAG TBCs.

Table 1 Comparison of properties of bulk YSZ and YAG TBCs

\begin{tabular}{lll}
\hline Material property & YSZ & YAG \\
\hline Melting point, ${ }^{\circ} \mathrm{C}$ & 2680 & 1970 \\
Maximum operating temperature, ${ }^{\circ} \mathrm{C}$ & 1200 & $>1500$ \\
Thermal conductivity at $1000{ }^{\circ} \mathrm{C}, \mathrm{W} \cdot \mathrm{m}^{-1} \mathrm{~K}^{-1}$ & $2.2-2.9(6-8 \mathrm{wt} . \%)(\operatorname{Ref} 27,28)$ & 3.2 at $1000{ }^{\circ} \mathrm{C}(\mathrm{Ref} 27)$ \\
Thermal expansion coefficient, $\mathrm{ppm} / \mathrm{K}$ & $9.5 \times 10^{-6}$ & $7.5 \times 10^{-6}$ \\
Density, g/cc & 6.1 & 4.55 \\
Vickers hardness, $\mathrm{GPa}$ & $\sim 13(\operatorname{Ref} 29)$ & $16.5-17(\operatorname{Ref} 30)$ \\
Fracture toughness, $\mathrm{MPa} \cdot \mathrm{m}^{0.5}$ & $5.3(\operatorname{Ref} 31)$ & $\sim 1.8$ at $25^{\circ} \mathrm{C}(\operatorname{Ref} 32)$ \\
\hline
\end{tabular}




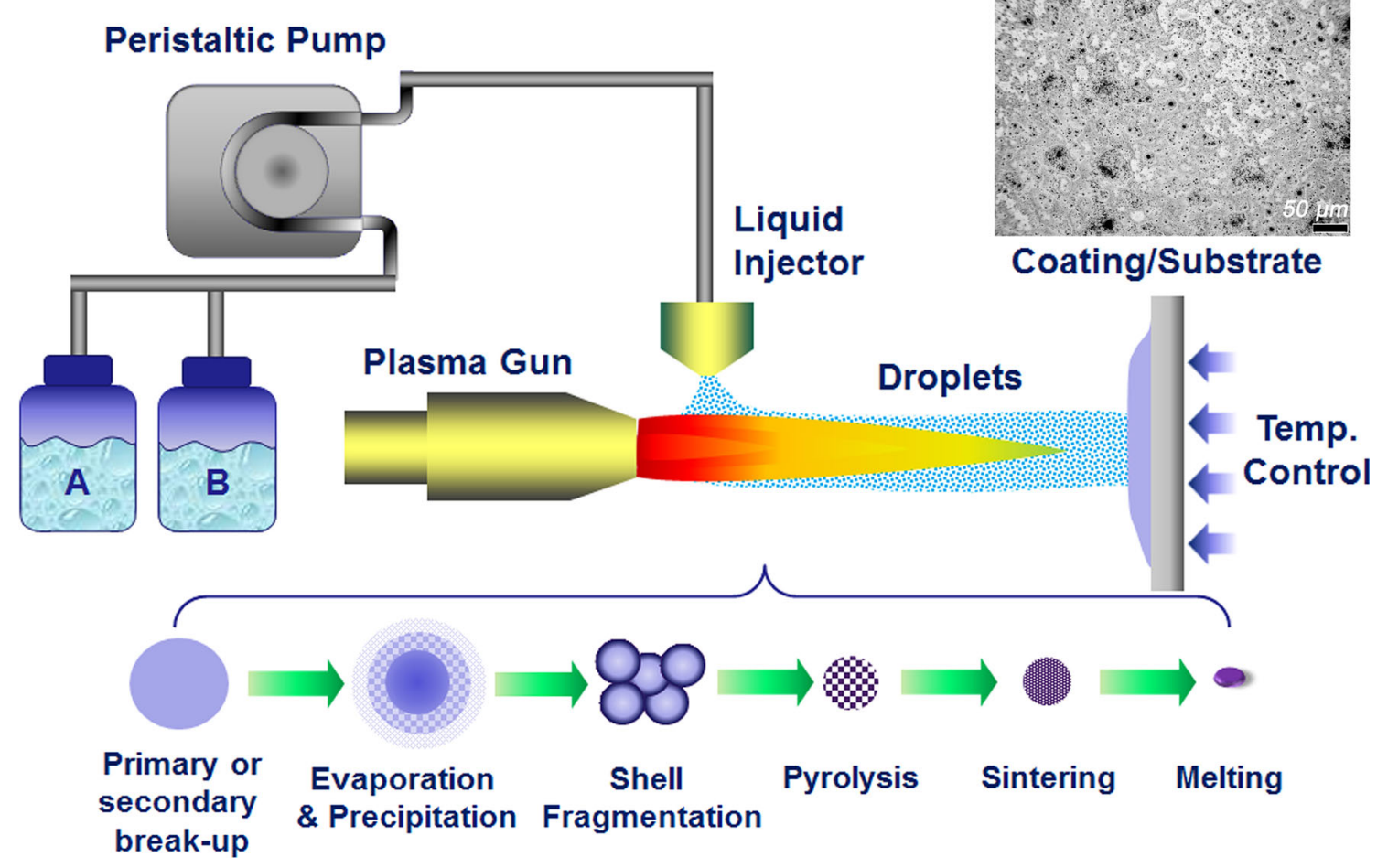

Fig. 1 Schematic of solution precursor plasma spray (SPPS) process

Table 2 SPPS process conditions for spraying YAG TBCs

\begin{tabular}{ll}
\hline Parameters & \\
\hline Plasma gun & Metco $9 \mathrm{MB}$, GP gun nozzle \\
Gun power & $45.5 \mathrm{~kW}$ \\
Primary gas/secondary gas & $\mathrm{Ar} / \mathrm{H}_{2}$ \\
Liquid injection mode & Atomization using BETE FC4 spray nozzles, 15 psi \\
& pressure \\
Liquid flow rates & $18-20 \mathrm{ml} / \mathrm{min}$ \\
Standoff distances & $35-37 \mathrm{~mm}$ \\
Traverse speed & $550 \mathrm{~mm} / \mathrm{s}$ \\
Raster scan step size & $2 \mathrm{~mm}$ \\
\hline
\end{tabular}

\section{SPPS YAG Coating Process}

The SPPS YAG coatings were deposited using the direct current (DC) plasma torch (Metco $9 \mathrm{MB}$, Sulzer Metco, Westbury, NY, USA), which was attached to a six-axis robotic arm. Argon and hydrogen were used as the primary and the secondary plasma gases, respectively. Compressed air was used as the solution precursor atomizing gas during the precursor injection. The schematic of SPPS process is shown in Fig. 1. A peristaltic pump was utilized for precursor delivery to an atomizing nozzle. Table 2 summarizes the SPPS YAG TBC deposition parameters.

\section{Microstructural Characterization and X-ray Diffraction}

YAG TBC samples were sectioned and embedded in a lowviscosity epoxy resin (Allied High Tech Products Inc., Rancho Dominguez, CA) for grinding with silicon carbide abrasive grinding papers before final polishing with diamond polishing suspensions. FEI field emission scanning electron microscope (Quanta 250 FEG, Hillsboro, OR) equipped with an energy dispersive $\mathrm{x}$-ray spectrometer was employed for cross-sectional microstructure characterization. Sputtered $\mathrm{Au} / \mathrm{Pd}$ coatings were applied using a Polaron E5100 SEM coating unit. An x-ray diffractometer (D2 Phaser, Bruker AXS, Madison, WI) was used to 
acquire the phase composition and evolution in the SPPS YAG TBC samples.

\section{Thermal Conductivity of SPPS YAG Coatings}

The thermal conductivity of the as-sprayed SPPS YAG coating was measured using the laser flash method (Netzsch LFA447, Burlington MA). Necessary specific heat capacity data were measured with modulated-DSC (TAQ100, TA Instruments, New Castle, DE). To increase the measurement accuracy, thick SPPS YAG coating $(>500 \mu \mathrm{m})$ was sprayed on 304 stainless steel substrates using the optimized spray conditions. After machining to the required size $(10 \mathrm{~mm} \times 10 \mathrm{~mm})$ for measurement, the free-standing testing samples were removed from the substrates by immersing in the nitric acid. The elevated temperature thermal conductivity was measured on a fee basis by Netzsch Instruments using a high temperature version of the laser flash device.

\section{Thermal Cyclic Life Test}

The thermal cyclic durability performance of the SPPS YAG and the baseline APS YSZ TBCs were compared in a programmable bottom-loading isothermal furnace (CM Furnaces Inc., Bloomfield, NJ) using 1-h cycles, consisting of 10-min heat-up, 40-min dwelling at 1121 and $1150{ }^{\circ} \mathrm{C}$ and 10-min air-forced cooling. Tests were also conducted with 8 -h cycles at $1150{ }^{\circ} \mathrm{C}$. In the test, the furnace controlling thermocouple was welded to the back of an uncoated superalloy substrate sitting among all test specimens so as to ensure that specimens were exposed to the correct temperature. Specimens were removed from the elevator platform upon failure (more than $50 \%$ spallation) and used to study the failure mechanisms.

\section{CMAS Resistance Paste Tests}

CMAS paste tests were conducted to evaluate CMAS-TBC interactions. A simulated CMAS composition with 4-component was used (Table 3). The CMAS was made from a pyrolyzed solution based on soluble nitrates and colloidal silica, with $\mathrm{pH}$ adjustments to maintain solubility accomplished using nitric acid. A CMAS concentration of

Table 3 4-component CMAS composition

\begin{tabular}{lcccc}
\hline Oxide & $\mathrm{SiO}_{2}$ & $\mathrm{CaO}$ & $\mathrm{Al}_{2} \mathrm{O}_{3}$ & $\mathrm{MgO}$ \\
\hline wt.\% & 52.3 & 37.1 & 7.1 & 3.5 \\
mol.\% & 51.5 & 39.2 & 4.1 & 5.2 \\
\hline
\end{tabular}

$2.5 \mathrm{mg} / \mathrm{cm}^{2}$ was chosen for the testing. A measured amount of CMAS powder was applied on sample surfaces soaked with DI water and subsequently was evenly spread over the coating surfaces. Three SPPS YAG and APS YSZ baseline samples were isothermally cycled to a hold temperature of $1180{ }^{\circ} \mathrm{C}$ using similar 1-h cycles, as in thermal cyclic life test. Sample failure was defined as more than $50 \%$ area spallation.

\section{Erosion Resistance of SPPS YAG TBCs}

Erosion resistance of SPPS YAG in comparison with APS YSZ baseline samples was measured at Applied Research Laboratory at Penn State University (University Park, PA) using conditions as listed in Table 4.

\section{Coating Density}

The coating density was calculated by dividing the weight of the coating, i.e., the change of weight after the deposition, by the volume. The coating thickness was determined from SEM micrographs. This gives an average coating density, assuming the porosity is uniformly distributed.

\section{Experimental Results and Discussion}

\section{YAG Precursor}

YAG solution precursors were prepared by mixing stoichiometric amounts of yttrium and aluminum nitrates. The viscosity of the YAG precursors measured is between 4.5 and $5.0 \mathrm{mPa}$.s. The thermal characteristics of $80^{\circ} \mathrm{C}$ dried YAG precursor are shown in Fig. 2. The endothermic peak below $200{ }^{\circ} \mathrm{C}$ is related to the evaporation of water and bonded water, while the exothermic decomposition reaction occurs at $250{ }^{\circ} \mathrm{C}$. The sharp exothermic peak at $930{ }^{\circ} \mathrm{C}$ is associated with the crystal formation of YAG phase (Ref 43). Since the precursor contains predominantly nitrates (oxidizer), no combustion reactions are observed.

Table 4 Testing conditions for erosion resistance

\begin{tabular}{ll}
\hline Conditions & \\
\hline Impact angle & $90^{\circ}$ and $30^{\circ}$ \\
Particle size & $50 \mu \mathrm{m}$ alumina media \\
& $\quad(240$ grit BFA $)$ \\
Impact speed, & 80 for $90^{\circ}$ and 100 for $30^{\circ}$ \\
$\mathrm{m} / \mathrm{s}$ & \\
Standoff distance & $229 \mathrm{~mm}$ \\
Mask size & $12.7 \mathrm{~mm}$ \\
Feed rate & $2 \mathrm{~g} / \mathrm{min}$
\end{tabular}




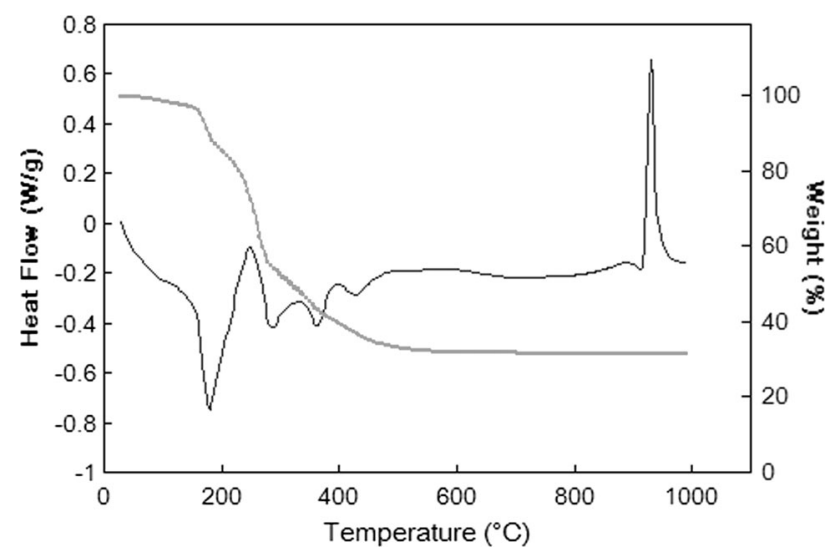

Fig. 2 Thermal characteristic of YAG precursor

\section{Microstructure and Microhardness}

Figure 3(a) shows a cross section scanning electron microscope (SEM) image of an as-sprayed SPPS YAG coating on a bond-coated superalloy substrate. It shows that the SPPS YAG TBC microstructure does contain vertical cracks. The SPPS YAG TBCs for all key property tests were sprayed using the optimized conditions (Table 2) and have a thickness of $220-250 \mu \mathrm{m}$ with Vickers' microhardness of $258 \pm 28$ and porosity of $30.5 \pm 2.5 \mathrm{vol} . \%$. As indicated in "Coating Density" Section, the porosity measurement used assumes the porosity is uniformly distributed. Clearly in Fig. 3(a), the porosity is very inhomogeneously distributed, with most of the porosity in the IPBs and very little porosity in the regions between IPBs. The vertical crack spacing varies, but has an average value of $107 \pm 34$ microns. The coating also contains planar porosity layers (IPBs), which have spacing
15-20 $\mu \mathrm{m}$ and are formed between two adjacent spray passes during coating deposition. High-magnification SEM image (Fig. 3a inset) shows that micron-sized porosity and particles are the main components of the IPBs. The SEM image of baseline sample (Fig. 3b) shows typical APS YSZ microstructure with uniformly distributed splat boundaries and porosities $(\sim 15 \%)$. The APS YSZ coating has Vickers' microhardness of $380 \pm 30$ in the vertical cross section plane.

\section{Crystallinity and Phase Stability}

Figure 4(a) shows the $\mathrm{x}$-ray diffraction pattern of the assprayed SPPS YAG coating, indicating a dominant YAG phase (JCPDS No. 33-0040) with a small amount of intermediate YAP $\left(\mathrm{YAlO}_{3}\right)$ phase. Such off stoichiometry of YAG coatings on the $\mathrm{Y}_{2} \mathrm{O}_{3}$-rich side of $\mathrm{Y}_{2} \mathrm{O}_{3}-\mathrm{Al}_{2} \mathrm{O}_{3}$ system is due to the loss of $\mathrm{Al}$ species during plasma spray (Ref 44,45 ). After sintering at $1600{ }^{\circ} \mathrm{C}$ for $100 \mathrm{~h}$, no phase transformation is observed (Fig. 4b). Figure 4(c) shows the normalized hardness of SPPS YAG and baseline APS YSZ TBCs before and after sintering at $1600{ }^{\circ} \mathrm{C}$ for $100 \mathrm{~h}$. The SPPS YAG TBC had almost no hardness change (Fig. 5), while the hardness of APS YSZ increased 22\%. These indicate excellent phase stability and sintering resistance of SPPS YAG TBC, in comparison with OEM APS YSZ. TBC. It is well-known that YSZ TBCs suffer from unfavorable phase transformations above $1200^{\circ} \mathrm{C}$. In this study, YAG TBCs has demonstrated potential to be used at significant higher temperatures (e.g., $>200{ }^{\circ} \mathrm{C}$ ) than typical APS YSZ TBCs.

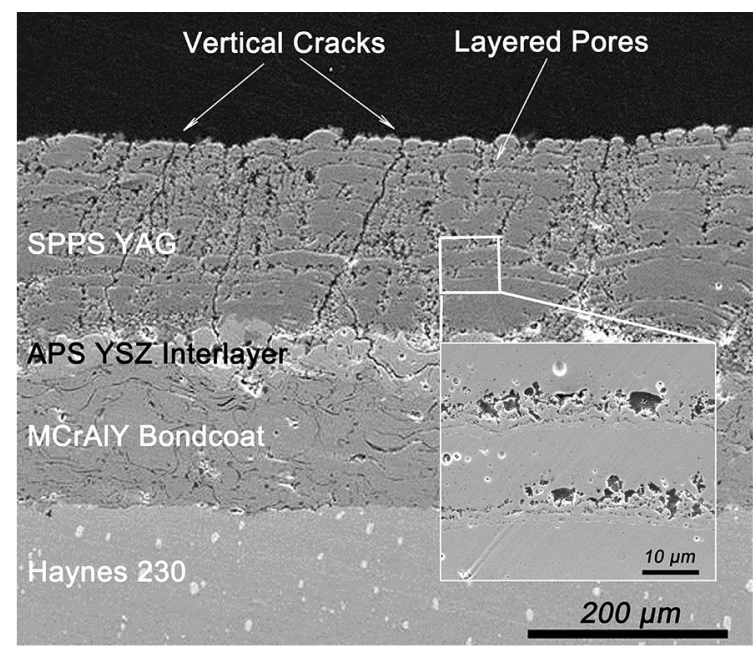

(a)

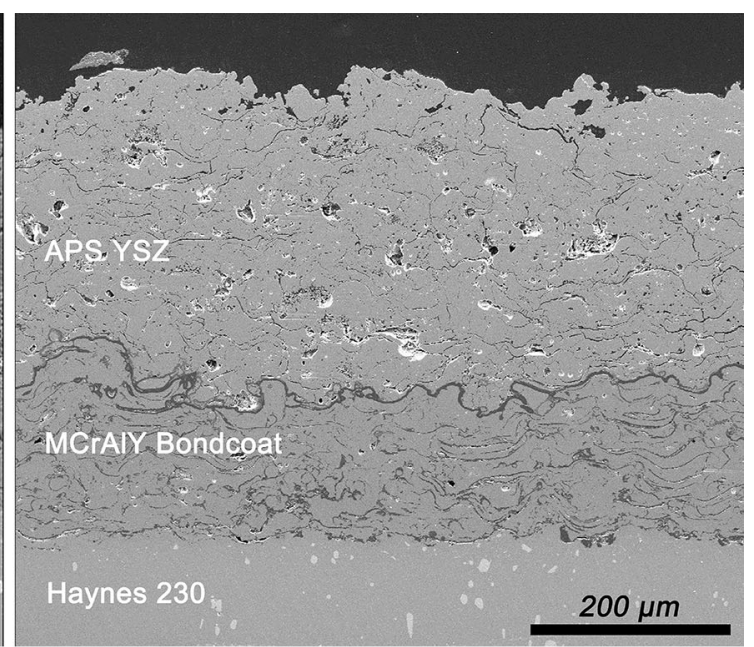

(b)

Fig. 3 (a) SEM cross section image of SPPS YAG (inset: high-magnification image of high porosity layers); (b) SEM cross section image of APS YSZ 

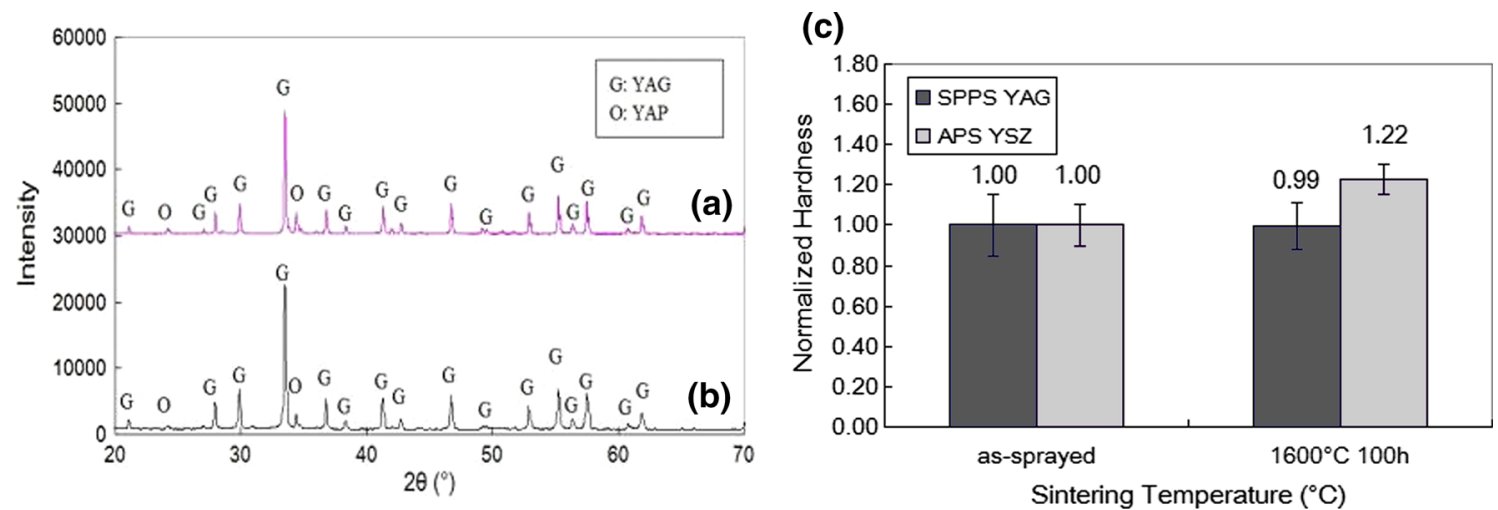

Fig. 4 (a) XRD patterns of SPPS YAG as-sprayed; (b) after sintering at $1600{ }^{\circ} \mathrm{C}$ for $100 \mathrm{~h}$ and (c) normalized hardness of SPPS YAG and APS YSZ before and after sintering at $1600{ }^{\circ} \mathrm{C}$ for $100 \mathrm{~h}$
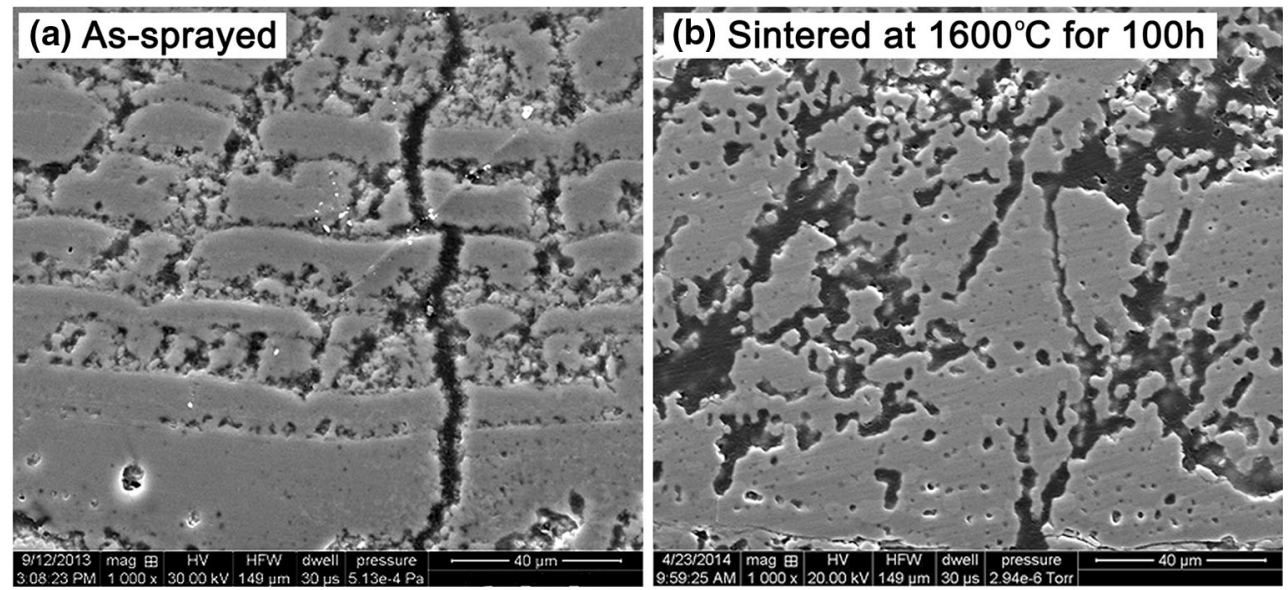

Fig. 5 Microstructural evolution of SPPS YAG TBCs after $100 \mathrm{~h}$ of sintering at $1600{ }^{\circ} \mathrm{C}$. The measured Vickers hardness values are (a) $380 \pm 185$ and (b) $379 \pm 139$
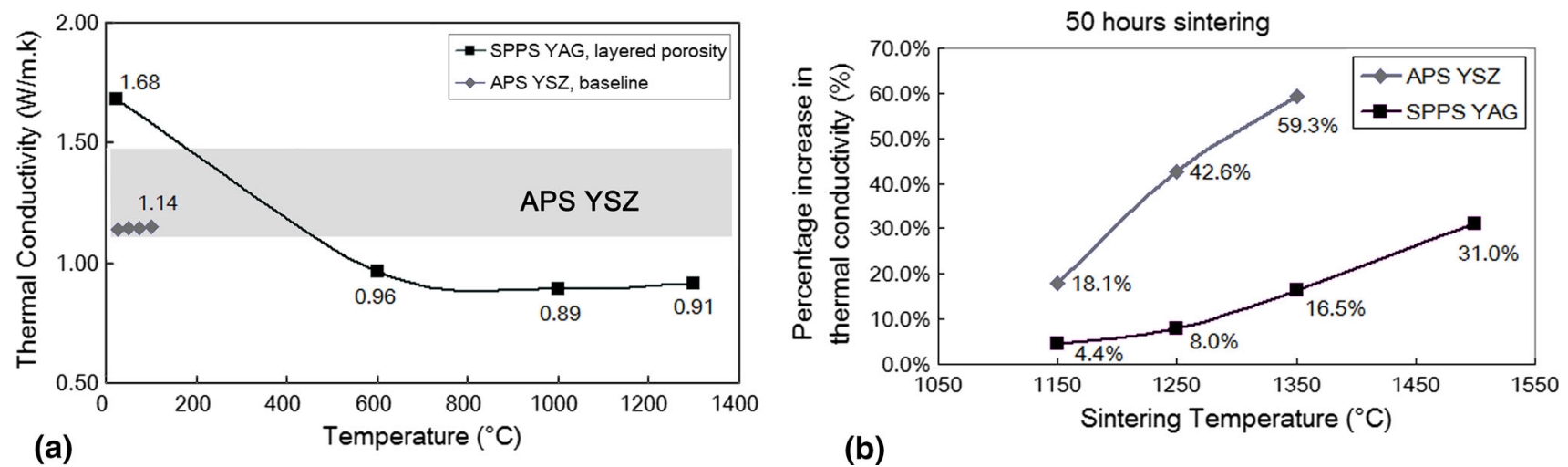

Fig. 6 (a) Thermal conductivity of SPPS YAG and APS YSZ as a function of temperature (the error associated with the measurements is $\pm 5 \%$ ). (b) Thermal conductivity change for thermally aged SPPS YAG and APS YSZ coatings

\section{Thermal Conductivity and Sintering Resistance}

Figure 6(a) shows the thermal conductivity of SPPS YAG as a function of temperature to $1300{ }^{\circ} \mathrm{C}$. Thermal conductivity of a baseline OEM APS YSZ sample was also measured to $200{ }^{\circ} \mathrm{C}$ which can be extrapolated to higher temperatures based on literature data (Ref 46, 47). The thermal conductivity of SPPS YAG decreases continually from $1.68 \mathrm{~W} \cdot \mathrm{m}^{-1} \mathrm{~K}^{-1}$ at room temperature to $0.91 \mathrm{~W} \cdot \mathrm{m}^{-1} \mathrm{~K}^{-1}$ at $1300{ }^{\circ} \mathrm{C}$. At temperatures greater than 
$600^{\circ} \mathrm{C}$, SPPS YAG TBC shows lower thermal conductivity than those of typical APS YSZ $\left(1.1-1.5 \mathrm{~W} \cdot \mathrm{m}^{-1} \mathrm{~K}^{-1}\right)$ and baseline APS YSZ $\left(1.14 \mathrm{~W} \cdot \mathrm{m}^{-1} \mathrm{~K}^{-1}\right.$ at $\left.200{ }^{\circ} \mathrm{C}\right)$. The measured thermal conductivity of SPPS YAG coating is also significantly lower than the calculated values, assuming uniformly distributed porosity (e.g., $0.89 \mathrm{~W} \cdot \mathrm{m}^{-1} \mathrm{~K}^{-1}$ measured versus $1.98 \mathrm{~W} \cdot \mathrm{m}^{-1} \mathrm{~K}^{-1}$ (Ref 48 ) calculated at $1000^{\circ}$ C). Porosity in TBCs can interrupt the direct flow of heat, forcing longer conduction paths and thereby reduce thermal conductivity. By arranging the pores in layers normal to the direction of heat flow, it becomes more difficult for the heat flow to find a path that avoids porosity, without taking a longer path with high thermal resistance. Thus, engineered high porosity layers are more efficient than uniformly distributed porosities with the same volume fraction in reducing the thermal conductivity of SPPS TBCs, as demonstrated in SPPS YSZ system (Ref 39). Low thermal conductivity is one of the key property requirements for TBCs. Fully dense, large grain size YSZ with 6-8 wt. $\% \mathrm{Y}_{2} \mathrm{O}_{3}$ stabilization has a reported thermal conductivity in the range of $2.2-2.9 \mathrm{~W} \cdot \mathrm{m}^{-1} \mathrm{~K}^{-1}$, and typical APS YSZ coatings have an almost constant thermal conductivity value of $1.1-1.5 \mathrm{~W} \cdot \mathrm{m}^{-1} \mathrm{~K}^{-1}$ over a wide temperature range $\left(25-1200{ }^{\circ} \mathrm{C}\right)$ (Ref 27, 49). Based on the measurements by Padture and Klemens, dense YAG ceramic's thermal conductivity continuously decreases with temperature from $8.7 \mathrm{~W} \cdot \mathrm{m}^{-1} \mathrm{~K}^{-1}$ at $23{ }^{\circ} \mathrm{C}$ to $3.2 \mathrm{~W} \cdot \mathrm{m}^{-1} \mathrm{~K}^{-1}$ at $1000{ }^{\circ} \mathrm{C}(\operatorname{Ref} 27)$, which makes it closer to that of YSZ at high temperature. In this work, SPPS YAG TBC with low density in the form of layered porosity has demonstrated thermal conductivity $\left(0.91 \mathrm{~W} \cdot \mathrm{m}^{-1} \mathrm{~K}^{-1}\right) \quad 20-30 \%$ lower than that of typical APS YSZ TBCs at temperatures greater than $1000{ }^{\circ} \mathrm{C}$.

To assess changes in thermal conductivity resulting from sintering at elevated temperatures, SPPS YAG TBCs and baseline APS YSZ TBCs were aged for $50 \mathrm{~h}$ at temperatures up to $1500{ }^{\circ} \mathrm{C}$. The room-temperature thermal conductivity was measured before and after thermal exposure and is shown in Fig. 6(b) as a percentage increase in thermal conductivity. Sintering and the subsequent reduction in porosity and microcracks contributes to the rising conductivity in both coatings. However, the thermal conductivity increase in SPPS YAG is significantly less than that of baseline OEM APS YSZ specimens by a factor of 4-5. The increase in SPPS YAG TBCs sintered at $1500^{\circ}$ $\mathrm{C}$ is still less than that of APS YSZ at $1250{ }^{\circ} \mathrm{C}$. While ascoated values of thermal conductivity are useful, engine manufacturers and their airline and utility customers are most interested in thermal conductivity after thermal exposure. The retention of low thermal conductivity of SPPS YAG TBCs is a result of the much greater sintering resistance and stability of the porosity in SPPS YAG TBCs compared to that in APS YSZ. The superior sintering resistance in SPPS YAG TBCs can be attributed to three potential factors: (a) APS YSZ TBCs have narrow splat interfaces that are susceptible to sintering. SPPS YAG coatings have both fine closed pores as well as large pores and vertical cracks. Because of the dimensions of these microstructural features, fine closed pores will be densified at $1600{ }^{\circ} \mathrm{C}$, yet the large pores and vertical cracks are hardly affected by the volume and surface diffusion in the coating during sintering, as shown in Fig. 5. (b) Silica is a known impurity at grain boundaries in APS YSZ TBCs that promotes sintering, while such an impurity is not present in the SPPS precursor and coating. (c) YSZ by nature is a solid solution of $\mathrm{Y}_{2} \mathrm{O}_{3}$ and $\mathrm{ZrO}_{2}$. Due to the difference in ionic radii (104 pm versus $86 \mathrm{pm}$ ) and valence states ( 3 versus 4) between yttrium and zirconium cations, crystal defects are prominent in $\mathrm{ZrO}_{2}$ crystal structure, and they will facilitate lattice diffusion. YAG on the other hand is a line compound in the equilibrium $\mathrm{Y}_{2} \mathrm{O}_{3}-\mathrm{Al}_{2} \mathrm{O}_{3}$ phase diagram with a more complex crystal structure. Therefore, lattice diffusion is slower, which in turn contributes to good sintering resistance. Reference 24 shows YAG's oxygen diffusion rate is 10 times slower than that of YSZ. All three factors are believed to be responsible for the improved sintering resistance of SPPS YAG TBCs.

\section{Thermal Cyclic Durability}

The thermal cyclic durability of SPPS YAG and APS YSZ TBCs was evaluated in a number of tests, at 1121 and $1150{ }^{\circ} \mathrm{C}$, and with short hold times of $1 \mathrm{~h}$ applicable to aircraft gas turbines and longer hold times of $8 \mathrm{~h}$ more applicable to land-based gas turbines. Figure 7 shows that for all temperature/cycle duration conditions, the cyclic lives of SPPS YAG TBCs are greater by $22-28 \%$ than APS YSZ TBCs, despite YAG's lower coefficient of thermal expansion and higher thermal expansion mismatch strains compared to YSZ. Spallation was found to be at the TBC/

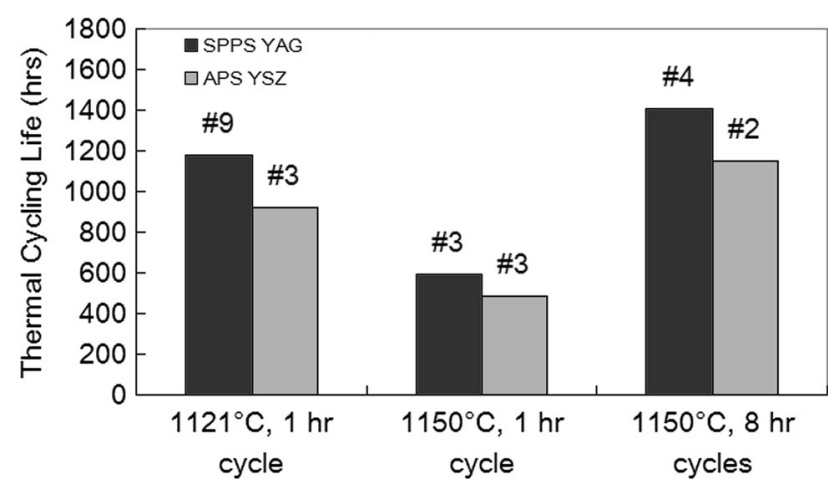

Fig. 7 Thermal cyclic durability of APS YSZ baseline and SPPS YAG specimens at 1121 and $1150{ }^{\circ} \mathrm{C}$. The number of specimens tested for each condition is shown at the top of each bar 
TGO interfaces in all cases (Fig. 8a and b), indicating that the thermal cyclic durability was likely governed by the stresses in the ceramic associated with TGO thickening (Ref 50). For a strain-tolerant microstructure to be effective, it is necessary to have closely spaced vertical cracks. An elastic analysis indicates that a factor of 10 stress reduction can be achieved for inter-crack columns that are twice as tall as they are wide (Ref 51). Measurement shows the SPPS YAG TBCs with a coating thickness of 220-250 microns have a vertical crack spacing which is about $107 \mu \mathrm{m}$, and thus a column height to width ratio of slightly over two, which contributes to enhanced strain tolerance and cyclic life of the TBC coatings.

\section{Resistance to CMAS Attack}

Gas-turbine engines are susceptible to attacks by deposits of calcium magnesium aluminosilicate (CMAS) ingested with the intake air at high temperatures, and CMAS resistance is a critical TBC property, especially at elevated temperatures above $1200{ }^{\circ} \mathrm{C}$. The reactivity of YAG to CMAS was initially evaluated by mixing powders of YAG and CMAS in 80:20 ratio and exposing the mixed powders to $1500{ }^{\circ} \mathrm{C}$ for $1 \mathrm{~h}$. Figure 9 shows, using XRD, that there are no new phases created and SEM image (Fig. 9 inset) indicates clear YAG/CMAS boundary without reactants. In addition, YAG and YSZ TBCs were exposed to CMAS and samples were isothermally cycled to $1180{ }^{\circ} \mathrm{C}$ using $1-\mathrm{h}$ cycles after the application of the 4-component CMAS at a dose of $2.5 \mathrm{mg} / \mathrm{cm}^{2}$. The dose of $2.5 \mathrm{mg} / \mathrm{cm}^{2}$ CMAS was selected as the CMAS level needed to initiate TBC damage (Ref 52).

Cyclic life data of APS YSZ and SPPS YAG TBCs exposed to CMAS are shown in Fig. 10. All APS YSZ baseline specimens failed within 2 thermal cycles, while the cyclic life of SPPS YAG reached an average of 142 cycles. In comparison with their thermal cyclic durability at $1180{ }^{\circ} \mathrm{C}$ without CMAS (147 cycles for APS YSZ and 179 for SPPS YAG), it is clear that a sharp reduction in cyclic life occurred for APS YSZ TBC, but not for SPPS YAG TBCs. The APS YSZ TBCs cracked within YSZ ceramic, along splat boundaries (Fig. 11a), and the highmagnification image in Fig. 11(b) shows that significant reactions and morphological transformations have occurred in the top region in the YSZ coating, generating globular particles that formed an interconnected network and microcracks due to CMAS penetration. The vulnerability of YSZ TBCs to the molten CMAS attack is consistent with the observations of Krämer et al. (Ref 53). The SPPS YAG coating failed at the YAG/TGO interface (Fig. 11c) with no interaction of CMAS with YAG observed in situ, while CMAS was mostly captured on the coating surface as circular droplets (Fig. 11d), indicating low wettability between YAG and CMAS. An EDS line scan for net counts of calcium was also conducted from the CMAS tested TBCs to a depth of 60 microns. This is shown in Fig. 12. From the line scan, the calcium penetration in YAG is $\sim 13$ microns, while in APS YSZ the penetration is at least $\sim 57$ microns. In another study of CMAS interaction with SPPS YAG and APS YSZ performed by our group with higher CMAS concentration of $10 \mathrm{mg} / \mathrm{cm}^{2}$ (Ref 54), XRD of the failed top surface of APS YSZ coating revealed severe reaction and formation of calcium zirconium oxide, calcium silicate and calcium oxide. Given the low reactivity of YAG to CMAS as shown in Fig. 9, it is not surprising that there is little chemical attack. However, absent reactivity, it is surprising that the YAG coating was infiltrated to a lower depth than the YSZ. To decisively determine the reason for this would require full understanding of all the factors that appear as variables in the Washburn equation including, crack width, viscosity, wetting angle and surface tension, as well as the effect of side channels (IPBs in this case) that move CMAS laterally. At the present time, the exact cause of the excellent
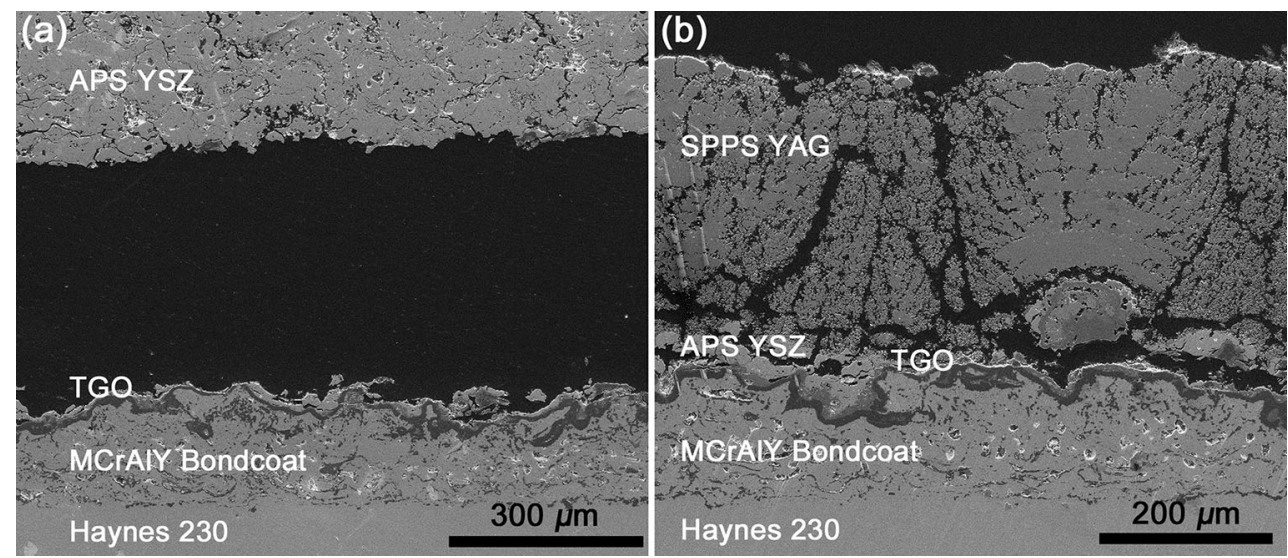

Fig. 8 SEM images of failed (a) APS YSZ and (b) SPPS YAG specimens after thermal cycling at $1150{ }^{\circ} \mathrm{C}$ 
Fig. 9 XRD pattern and SEM image of YAG/CMAS aged at $1500{ }^{\circ} \mathrm{C}$

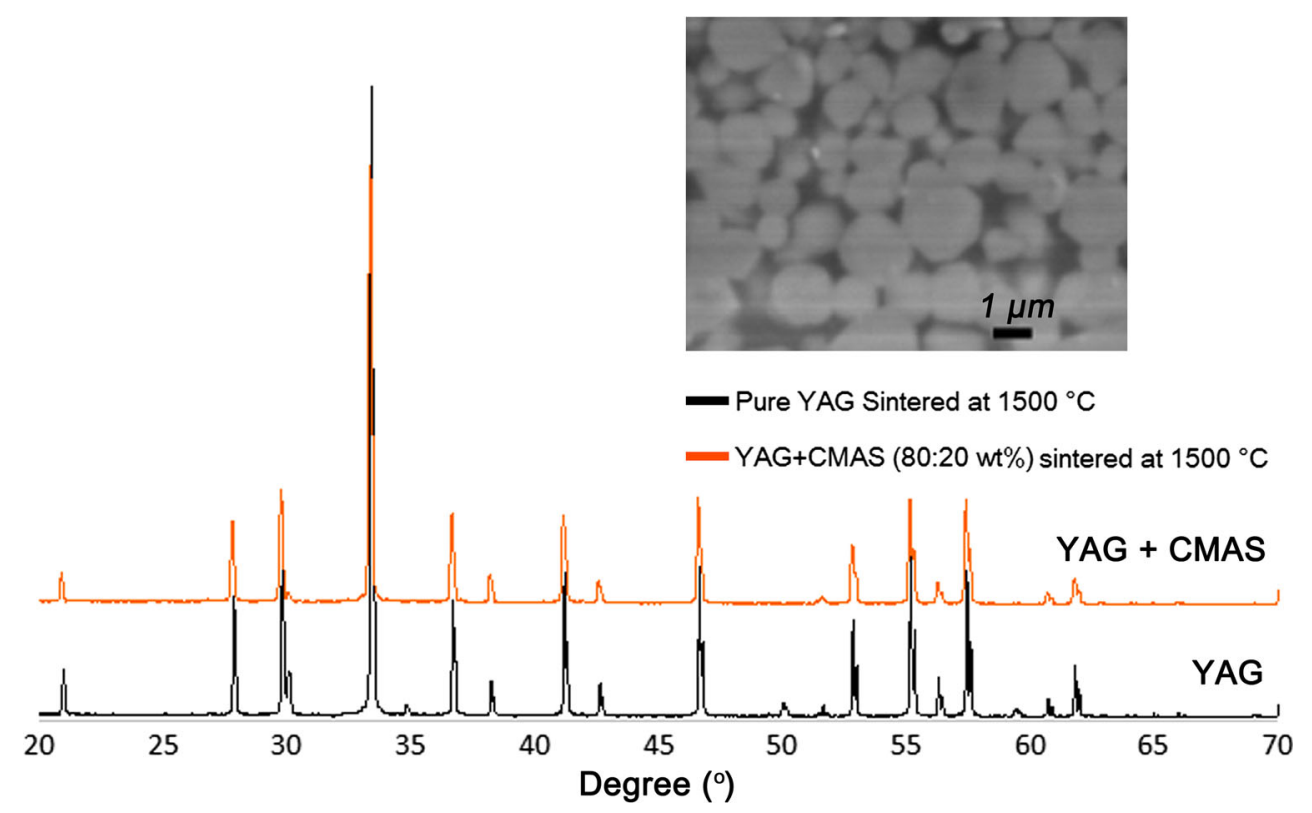

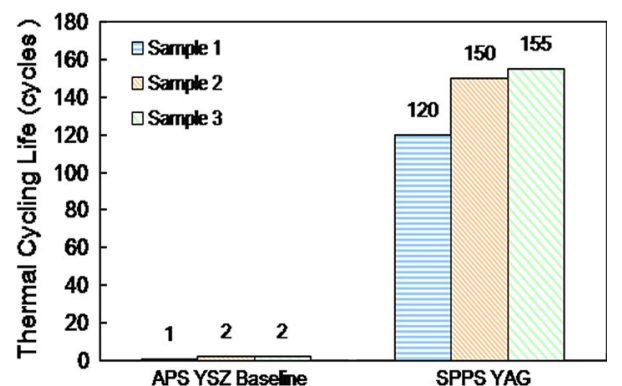

Fig. 10 Cyclic life of APS YSZ and SPPS YAG TBCs in CMAS paste tests

performance of YAG in CMAS is an important open question.

Molten CMAS is known to interact with TBCs both chemically, by dissolving the ceramic and reprecipitating it as a new or modified phase, and thermomechanically, by infiltrating the porosity and degrading the strain tolerance. This work has demonstrated that SPPS YAG TBCs have outstanding CMAS resistance compared to APS YSZ. It has been shown that CMAS reactivity can be explained by the optical basicity (OB) model (Ref 55). TBCs that have calculated optical basicity values closer to that of CMAS will have less reactivity. The OB difference between YSZ (0.87) and CMAS (0.64) has a relative high value at 0.23 , while OB value of YAG is calculated to be 0.7 , leading to a difference of only 0.06 and an expectation of much lower reactivity. But, molten CMAS can penetrate pores and cracks and, upon cooling and solidifying, produces a loss of strain tolerance and additional thermal expansion mismatch strains. This did not happen significantly in the case of the SPPS YAG TBC.

\section{Erosion Performance}

Figure 13 shows the results of erosion tests of SPPS YAG and baseline APS YSZ specimens conducted using both $30^{\circ}$ and $90^{\circ}$ impingement angles with $50 \mu \mathrm{m} \mathrm{Al}_{2} \mathrm{O}_{3}$ particles at 100 and $80 \mathrm{~m} / \mathrm{s}$ speed, respectively. The results show that SPPS YAG has better erosion resistance in both $90^{\circ}$ and $30^{\circ}$ impingement tests than those of APS YSZ specimens $\left(0.23\right.$ versus $0.65 \mathrm{~g} / \mathrm{kg}$ at $90^{\circ}$ and 0.18 versus $0.66 \mathrm{~g} / \mathrm{kg}$ at $30^{\circ}$ ). Even after coating porosity and density are taken into consideration, SPPS YAG still outperforms APS YSZ baseline samples in the thickness loss erosion rate $\left(0.57\right.$ versus $1.00 \mathrm{~mm} / \mathrm{kg}$ at $90^{\circ}$ and 0.45 versus $0.91 \mathrm{~mm} / \mathrm{kg}$ at $30^{\circ}$ ). It is generally considered that erosion resistance improves with higher hardness and toughness (Ref 56). Bulk YAG's toughness is less than that of YSZ $\left(1.8 \mathrm{MPa} \mathrm{m}^{1 / 2}\right.$ versus $\left.5.3 \mathrm{MPa} \mathrm{m}^{1 / 2}\right)$, but its hardness is greater (16.5-17 GPa of YAG versus $\sim 13 \mathrm{GPa}$ of YSZ) as shown in Table 1, which could be a reason of good erosion resistance of SPPS YAG (Ref 57). It is previously shown that the indentation toughness of a SPPS YSZ TBCs had a fivefold increase compared to that of the APS 7YSZ TBCs, which resulted in a significantly extended thermal cyclic life of the SPPS YSZ TBCs compared to conventional APS YSZ (Ref 40). Based on the results presented, it is considered that higher hardness along with the possible increased YAG toughness leads to the improved SPPS YAG erosion resistance. 

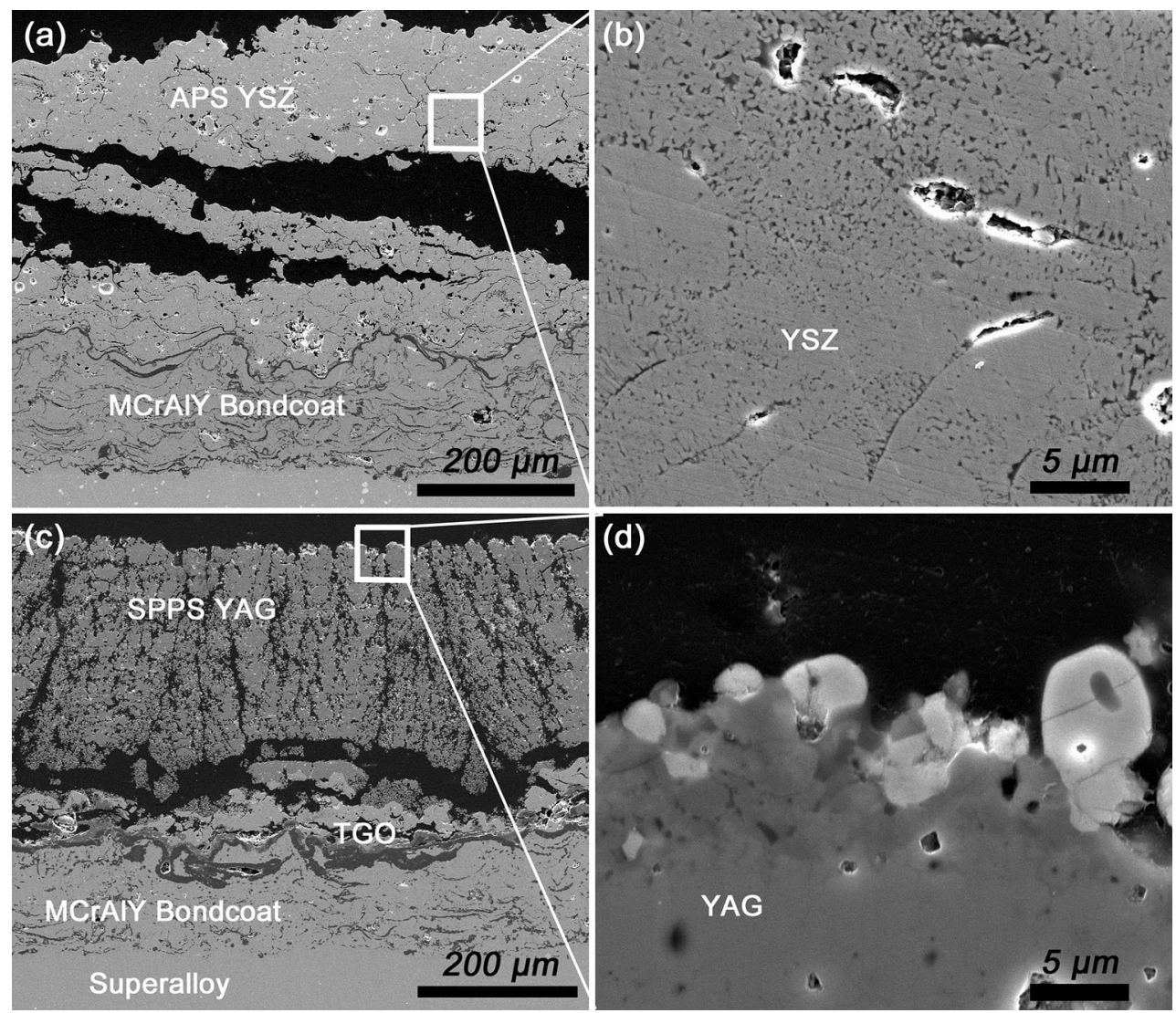

Fig. 11 (a) SEM image of APS YSZ sample failed with CMAS at 2 cycles; (b) CMAS interaction with YSZ; (c) SPPS YAG sample failed in CMAS at 144 cycles and (d) surface of failed SPPS YAG sample
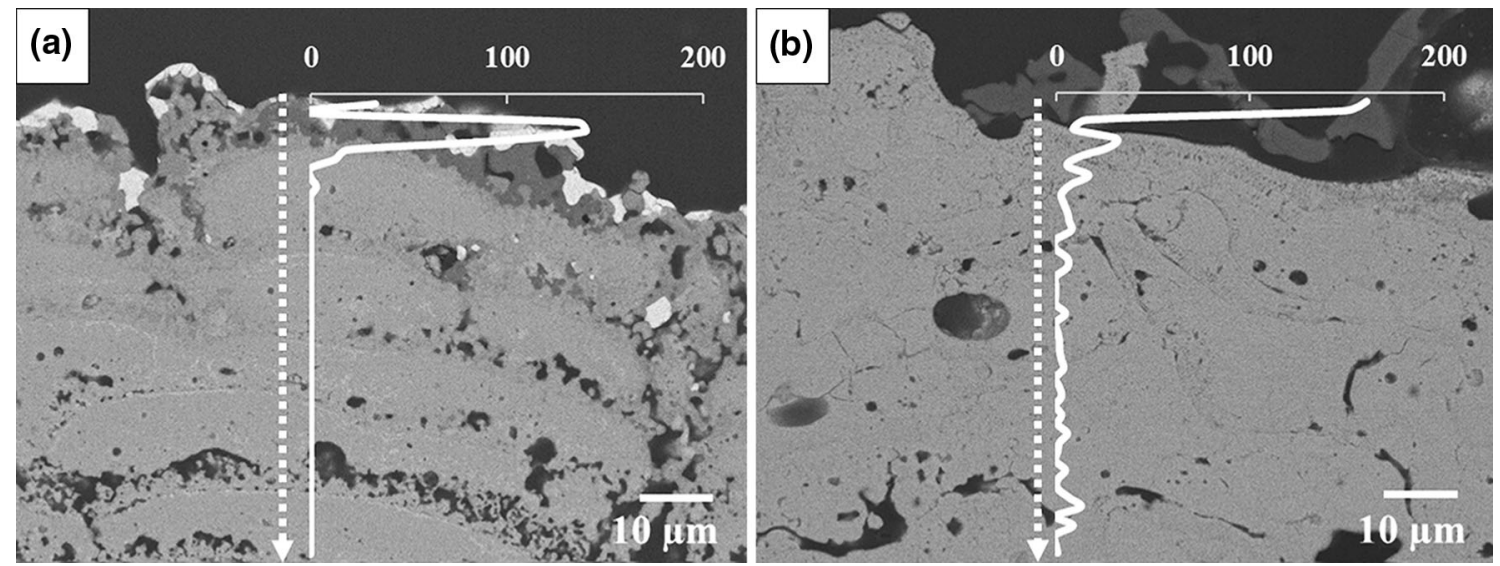

Fig. 12 EDS line scan data for net counts of calcium conducted on TBCs' from surface to a depth of 60 microns for (a) CMAS tested SPPS YAG TBCs and (b) CMAS tested APS YSZ TBCs

\section{Conclusions}

The driving force for advanced TBC development has been higher temperature capability and lower thermal conductivity. Extensive efforts have been focused on developing new generation TBC materials, and it has been shown that it is difficult for a new TBC to achieve all the critical properties be superior to the current YSZ TBCs. In this work, by introducing unique engineered microstructures, generated using the SPPS process, it has been demonstrated that an existing material, YAG, can meet and exceed all the major performance standards of current state-of-the-art air plasma sprayed YSZ. SPPS YAG TBCs exhibit about 30\% lower thermal conductivity at elevated temperatures than a 

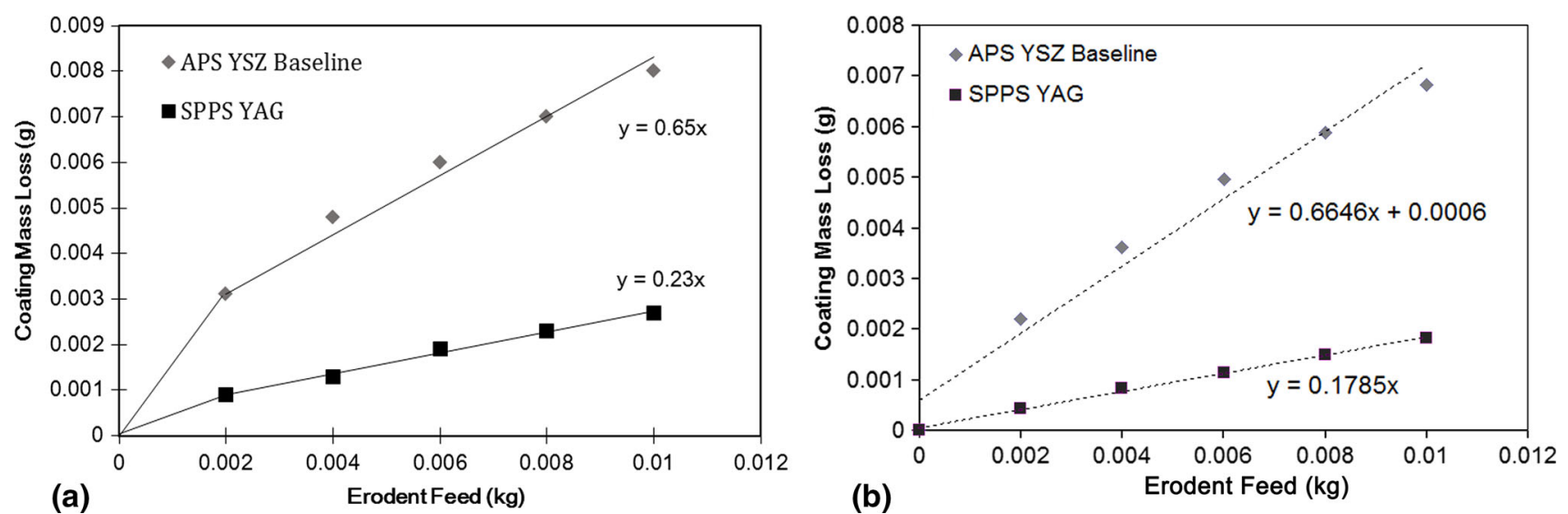

Fig. 13 Erosion performance of APS YSZ and SPPS YAG TBCs at (a) $90^{\circ}$ and (b) $30^{\circ}$ tests

typical APS YSZ used for comparison in this study. Based on the data presented for thermal stability, sinter resistance and CMAS resistance, SPPS YAG TBCs have the potential to be used at temperatures $>200{ }^{\circ} \mathrm{C}$ higher than YSZ TBCs. In addition, unlike most higher temperature coatings SPPS YAG erosion performance is superior to that of APS YSZ. It is suggested that the SPPS process can also be extended to other advanced TBC candidates to overcome cases of limited thermal cyclic durability and erosion resistance with reduced thermal conductivity.

Acknowledgments This research is supported by the US Department of Energy, National Energy Technology Lab through the Small Business Technology Transfer (STTR) program award DESC0007544, program manager Dr. Patcharin Burke. The authors also would like to thank Prof. Douglas Wolfe at Penn State University for the erosion testing and discussion, and Dr. Balakrishnan Nair from HiFunda LLC for helpful discussion and suggestions.

\section{References}

1. R.A. Miller, Current Status of Thermal Barrier Coatings-An Overview, Surf. Coat. Technol., 1987, 30(1), p 1-11 (in English)

2. A.G. Evans, D.R. Mumm, J.W. Hutchinson, G.H. Meier, and F.S. Pettit, Mechanisms Controlling The Durability of Thermal Barrier Coatings, Prog. Mater Sci., 2001, 46(5), p 505-553 (in English)

3. N.P. Padture, M. Gell, and E.H. Jordan, Thermal Barrier Coatings for Gas-Turbine Engine Applications, Science, 2002, 296(5566), p 280-284 (in English)

4. R. Vassen, A. Stuke, and D. Stöver, Recent Developments in the Field of Thermal Barrier Coatings, J. Therm. Spray Technol., 2009, 18(2), p 181-186 (in English)

5. C.G. Levi, Emerging Materials and Processes for Thermal Barrier Systems, Curr. Opin. Solid State Mater. Sci., 2004, 8(1), p 77-91 (in English)

6. X.Q. Cao, R. Vassen, and D. Stover, Ceramic Material for Thermal Barrier Coatings, J. Eur. Ceram. Soc., 2004, 24(1), p 110 (in English)

7. D. Stover, G. Pracht, H. Lehmann, M. Dietrich, J.-E. Doring, and R. Vassen, New Material Concepts for The Next Generation of
Plasma Sprayed Thermal Barrier Coatings, J. Therm. Spray Technol., 2004, 13(1), p 76-83 (in English)

8. D.R. Clarke, M. Oechsner, and N.P. Padture, Thermal Barrier Coatings for More Efficient Gas-turbine Engines, MRS Bull., 2012, 37(10), p 891-898 (in English)

9. S. Ghosh, Thermal Barrier Ceramic Coatings - A Review, Advanced Ceramic Processing, A. M. A. Mohamed, Ed., InTech, 2015, Chapter 5, https://doi.org/10.5772/61346.

10. D.R. Clarke and S.R. Phillpot, Thermal Barrier Coating Materials, Mater. Today, 2005, 8(6), p 22-29 (in English)

11. R.A. Miller, Thermal Barrier Coatings for Aircraft Engines: History and Directions, J. Therm. Spray Technol., 1997, 6(1), p 35-42 (in English)

12. R.L. Jones, R.F. Reidy, and D. Mess, Scandia, Yttria Stabilized Zirconia for Thermal Barrier Coatings, Surf. Coat. Technol., 1996, 82(1-2), p 70-76 (in English)

13. D.-J. Kim, Effect of $\mathrm{Ta}_{2} \mathrm{O}_{5}, \mathrm{Nb}_{2} \mathrm{O}_{5}$, and $\mathrm{HfO}_{2}$ Alloying on The Transformability of $\mathrm{Y}_{2} \mathrm{O}_{3}$-Stabilized Tetragonal $\mathrm{ZrO}_{2}, J . A m$. Ceram. Soc., 1990, 73(1), p 115-120 (in English)

14. D. Zhu and R.A. Miller, Sintering and Creep Behavior of PlasmaSprayed Zirconia and Hafnia-Based Thermal Barrier Coatings, Surf. Coat. Technol., 1998, 108-109, p 114-120 (in English)

15. F.M. Pitek and C.G. Levi, Opportunities for TBCs in The $\mathrm{ZrO}_{2-}$ $\mathrm{YO}_{1.5}-\mathrm{TaO}_{2.5}$ System, Surf. Coat. Technol., 2007, 201(12), p 6044-6050 (in English)

16. O. Fabrichnaya, S. Lakiza, C. Wang, M. Zinkevich, C.G. Levi, and F. Aldinger, Thermodynamic Database for The $\mathrm{ZrO}_{2}-\mathrm{YO}_{3 / 2}$ $\mathrm{GdO}_{3 / 2}-\mathrm{AlO}_{3 / 2}$ System and Application to Thermal Barrier Coatings, J. Phase Equilib. Diffus., 2006, 27(4), p 343-352 (in English)

17. R. Vassen, X.Q. Cao, F. Tietz, D. Basu, and D. Stoever, Zirconates as New Materials for Thermal Barrier Coatings, J. Am. Ceram. Soc., 2000, 83(8), p 2023-2028 (in English)

18. G. Suresh, G. Seenivasan, M.V. Krishnaiah, and P.S. Murti, Investigation of the Thermal Conductivity of Selected Compounds of Lanthanum, Samarium and Europium, J. Alloys Compd., 1998, 269(1-2), p L9-L12 (in English)

19. S. Kramer, J. Yang, and C.G. Levi, Infiltration-inhibiting Reaction of Gadolinium Zirconate Thermal Barrier Coatings with CMAS Melts, J. Am. Ceram. Soc., 2008, 91(2), p 576-583 (in English)

20. S. Mahade, N. Curry, S. Björklund, N. Markocsan, and P. Nylén, R, Vaßen, Erosion Performance of Gadolinium Zirconate-Based Thermal Barrier Coatings Processed by Suspension Plasma Spray, J. Therm. Spray Technol., 2017, 26(1-2), p 108-115 (in English) 
21. D. Shin and A. Hamed, Erosion Resistance Characteristics of Advanced APS TBC (GZO), in 40th International Conference and Exposition on Advanced Ceramics and Composites, Jan 24-29, 2016 (The American Ceramic Society, Daytona Beach, FL, 2016).

22. J.S. Abell, I.R. Harris, B. Cockayne, and B. Lent, An Investigation of Phase Stability in The $\mathrm{Y}_{2} \mathrm{O}_{3}-\mathrm{Al}_{2} \mathrm{O}_{3}$ System, J. Mater. Sci., 1974, 9(4), p 527-537 (in English)

23. N.P. Padture and P.G. Klemens, Low Thermal Conductivity in Garnets, J. Am. Ceram. Soc., 1997, 80(4), p 1018-1020 (in English)

24. Y.J. Su, R.W. Trice, K.T. Faber, H. Wang, and W.D. Porter, Thermal Conductivity, Phase Stability, and Oxidation Resistance of $\mathrm{Y}_{3} \mathrm{Al}_{5} \mathrm{O}_{12}$ (YAG)/ $\mathrm{Y}_{2} \mathrm{O}_{3}-\mathrm{ZrO}_{2}$ (YSZ) Thermal-Barrier Coatings, Oxide Met., 2004, 61(3), p 253-271 (in English)

25. C.M. Weyant and K.T. Faber, Processing-microstructure Relationships for Plasma-sprayed Yttrium Aluminum Garnet, Surf. Coat. Technol., 2008, 202(24), p 6081-6089 (in English)

26. J. P. Feist and J. R. Nicholls, Thermal Barrier Coatings and Coated Components, US Patent 2011/0236657, 2011.

27. J.R. Nicholls, K.J. Lawson, A. Johnstone, and D.S. Rickerby, Methods to Reduce The Thermal Conductivity of EB-PVD TBCs, Surf. Coat. Technol., 2002, 151-152, p 383-391 (in English)

28. S. Raghavan, H. Wang, R.B. Dinwiddie, W.D. Porter, and M.J. Mayo, The Effect of Grain Size, Porosity and Yttria Content on The Thermal Conductivity of Nano-crystalline Zirconia, Scripta Mater., 1998, 39(8), p 1119-1125 (in English)

29. H. Guo, T.J.M. Bayer, J. Guo, A. Baker, and C.A. Randall, Cold Sintering Process for $8 \mathrm{~mol} \% \mathrm{Y}_{2} \mathrm{O}_{3}$-stabilized $\mathrm{ZrO}_{2}$ Ceramics, $J$. Eur. Ceram. Soc., 2017, 37(5), p 2303-2308 (in English)

30. D.B. Sirdeshmukh, L. Sirdeshmukh, K.G. Subhadra, K. Kishan Rao, and S. Bal Laxman, Systematic Hardness Measurements on Some Rare Earth Garnet Crystals, Bull. Mater. Sci., 2001, 24(5), p 469-473 (in English)

31. A. Marinis, S.A. Aquilino, P.S. Lund, D.G. Gratton, C.M. Stanford, A.M. Diaz-Arnold, and F. Qian, Fracture Toughness of Yttria-Stablized Zirconia Sintered in Conventional and Microwave Ovens, J. Prosthet. Dent., 2013, 109(3), p 165-171 (in English)

32. W.R. Blumenthal and S.T. Taylor, High Temperature Fracture Toughness of Single Crystal Yttrium-Aluminum Garnet, Acta Mater., 1997, 45(7), p 3071-3078 (in English)

33. E.H. Jordan, C. Jiang, and M. Gell, Solution Precursor Plasma Spray (SPPS) Process: An Review with Energy Considerations, $J$. Therm. Spray Technol., 2016, 27(7), p 1153-1165 (in English)

34. L. Xie, X. Ma, E.H. Jordan, N.P. Padture, T.D. Xiao, and M. Gell, Deposition Mechanisms in the Solution-Precursor Plasma-Spray Process, Surf. Coat. Technol., 2004, 177-178, p 103-107 (in English)

35. L. Pawlowski, Suspension and Solution Thermal Spray Coatings, Surf. Coat. Technol., 2009, 203(19), p 2807-2829 (in English)

36. N.P. Padture, K.W. Schlichting, T. Bhatia, A. Ozturk, B. Cetegen, E.H. Jordan, M. Gell, S. Jiang, T.D. Xiao, P.R. Strutt, E. Garcia, P. Miranzo, and M.I. Osendi, Towards Durable Thermal Barrier Coatings with Novel Microstructures Deposited by SolutionPrecursor Plasma Spray, Acta Mater., 2001, 49(12), p 2251-2257 (in English)

37. M. Gell, E.H. Jordan, M. Teicholz, B.M. Cetegen, N.P. Padture, L. Xie, D. Chen, X. Ma, and J. Roth, Thermal Barrier Coatings Made by the Solution Precursor Plasma Spray Process, J. Therm. Spray Technol., 2008, 17(1), p 124-135 (in English)

38. E.H. Jordan, L. Xie, C. Ma, M. Gell, N. Padture, B. Cetegen, J. Roth, T.D. Xiao, and P.E.C. Bryant, Superior Thermal Barrier Coatings Using Solution Precursor Plasma Spray, J. Therm. Technol., 2004, 13(1), p 57-65 (in English)
39. E.H. Jordan, C. Jiang, J. Roth, and M. Gell, Low Thermal Conductivity Yttria-Stabilized Zirconia Thermal Barrier Coatings Using the Solution Precursor Plasma Spray Process, J. Therm. Spray Technol., 2014, 23(5), p 849-859 (in English)

40. A.D. Jadhav, N.P. Padture, F. Wu, E. Jordan, and M. Gell, Thick Ceramic Thermal Barrier Coatings with High Durability Deposited Using Solution Precursor Plasma Spray, Mater. Sci. Eng., A, 2005, 405(1-2), p 313-320 (in English)

41. A.D. Jadhav, N.P. Padture, E.H. Jordan, M. Gell, P. Miranzo, and E.R. Fuller, Jr., Low-Thermal-Conductivity Plasma-Sprayed Thermal Barrier Coatings with Engineered Microstructures, Acta Mater., 2006, 54(12), p 3343-3349 (in English)

42. E. H. Jordan, M. Gell, C Jiang, J. Wang, M. Gell, and B. Nair, High Temperature Thermal Barrier Coating Made by the Solution Precursor Plasma Spray Process, in ASME Turbo Expo: Power for Land, Sea, and Air, Volume 6: Ceramics; Controls, Diagnostics and Instrumentation; Education; Manufacturing Materials and Metallurgy, June 16-20, 2014 (Düsseldorf, Germany), International Gas Turbine Institute, 2014. https://doi.org/10.1115/ gt2014-26254.

43. K.R. Han, H.J. Koo, and C.S. Lim, A Simple Way to Synthesize Yttrium Aluminum Garnet by Dissolving Yttria Powder in Alumina Sol, J. Am. Ceram. Soc., 1999, 82(6), p 1598-1600 (in English)

44. D. Chen, E.H. Jordan, M.W. Renfro, and M. Gell, Dy:YAG Phosphor Coating Using the Solution Precursor Plasma Spray Process, J. Am. Ceram. Soc., 2009, 92(1), p 268-271 (in English)

45. L. Gu, S. Zhao, J. Xu, Y. Hui, X. Fan, B. Zou, Y. Wang, and X.Q. Cao, Phase Stability of Plasma Sprayed YAG-YSZ Composite Beads/Coatings at High Temperature, J. Eur. Ceram. Soc., 2013, 33(15-16), p 3325-3333 (in English)

46. S. Raghavan, H. Wang, R.B. Dinwiddie, W.D. Porter, and M. Mayo, The Effect of Grain Size, Porosity and Yttria Content on the Thermal Conductivity of Nanocrystalline Zirconia, Scripta Mater., 1998, 39(8), p 119-1125 (in English)

47. K.W. Schlichting, N.P. Padture, and P.G. Klemens, Thermal Conductivity of Dense and Porous Yttria-stabilized Zirconia, $J$. Mater. Sci., 2001, 36(12), p 3003-3010 (in English)

48. R.C. Progelhof, J.L. Throne, and R.R. Ruetsch, Methods for Predicting The Thermal Conductivity of Composite Systems: A Review, Polym. Eng. Sci., 1976, 16(9), p 615-625 (in English)

49. P. Morrell, Handbook of Properties of Technical Ceramics and Engineering Ceramics, Part I, Her Majesty's Stationery Office, London, 1989, p 87

50. C. Jiang, E.H. Jordan, A.B. Harris, M. Gell, and J. Roth, DoubleLayer Gadolinium Zirconate/Yttria-Stabilized Zirconia Thermal Barrier Coatings Deposited by the Solution Precursor Plasma Spray Process, J. Therm. Spray Technol., 2015, 24(6), p 895-906 (in English)

51. M. Karger, R. Vaßen, and D. Stöver, Atmospheric Plasma Sprayed Thermal Barrier Coatings with High Segmentation Crack Densities: Spraying Process, Microstructure and Thermal Cycling Behavior, Surf. Coat. Technol., 2011, 206(1), p 16-23 (in English)

52. R. Wellman, G. Whitman, and J.R. Nicholls, CMAS Corrosion of EB-PVD TBCs: Identifying the Minimum Level to Initiate Damage, Int. J. Refract. Met. Hard Mater., 2010, 28(1), p 124-132 (in English)

53. S. Krämer, J. Yang, C.G. Levi, and C.A. Johnson, Thermochemical Interaction of Thermal Barrier Coatings with Molten CaO-MgO- $\mathrm{Al}_{2} \mathrm{O}_{3}-\mathrm{SiO}_{2}$ (CMAS) Deposits, J. Am. Ceram. Soc., 2006, 89(10), p 3167-3175 (in English)

54. R. Kumar, E. Jordan, M. Gell, J. Roth, C. Jiang, J. Wang, and S. Rommel, CMAS Behavior of Yttrium Aluminum Garnet (YAG) 
and Yttria-Stabilized Zirconia (YSZ) Thermal Barrier Coatings, Surf. Coat. Technol., 2017, 327, p 126-138 (in English)

55. A.R. Krause, B.S. Senturk, H.F. Garces, G. Dwivedi, A.L. Ortiz, S. Sampath, and N.P. Padture, $2 \mathrm{ZrO}_{2}: \mathrm{Y}_{2} \mathrm{O}_{3}$ Thermal Barrier Coatings Resistant to Degradation by Molten CMAS: Part I, Optical Basicity Considerations and Processing, J. Am. Ceram. Soc., 2014, 97(12), p 3943-3949 (in English)
56. L.K. Ives and A.W. Ruff, Transmission and Scanning Electron Microscopy Studies of Deformation at Erosion Impacts Sites, Wear, 1978, 46(1), p 149-162 (in English)

57. F. Cernuschi, C. Guardamagna, S. Capelli, L. Lorenzoni, D.E. Mack, and A. Moscatelli, Solid Particle Erosion of Standard Advanced Thermal Barrier Coatings, Wear, 2016, 348-349, p 4351 (in English) 